\title{
Imovation in shaping \\ dynamic capabilities of organisations ${ }^{1}$
}

Prof. Kazimierz Krzakiewicz Poznań University of Economics

Prof. Szymon Cyfert Poznań University of Economics

\section{Introduction}

The management science literature abounds in publications which stress the importance of innovation and describe how innovations should be created and managed efficiently and effectively. These publications take the benefits of innovation for granted and their conclusions are clear: "innovate or die" should be the operating principle within organisations. Their authors set out to prove that imitators, if they survive at all, are doomed to poverty, having to live off the crumbs left by innovators. Imitation is portrayed as a spontaneous process without any clear goal which innovators can easily defend themselves against by erecting high barriers of entry and expanding the scale of their operations.

Imitation should be seen as an operating strategy that not only is coordinated with innovation but is also necessary for the effective use of innovative capabilities. While innovators make significant investments when paving the way, imitators enjoy a "free ride" as

1 The project was financed with the funds from the National Science Centre awarded based on the decision number DEC-2013/11 / B / HS4 / 00697. 
second movers, reducing not only their R\&D commitment but also advertising and promotion investment.

This article contributes to a discussion of imovation processes and their role in shaping dynamic capabilities and attempts to portray the essence and nature of imitation. It points to the need for a systemic approach to the deployment and management of imovation and identifies the benefits which copying what other organisations do can bring in terms of dynamic capabilities.

\section{The process of shaping dynamic capabilities within organisations}

The existing literature distinguishes between four and eight stages in shaping dynamic capabilities (Teece 2007, Eisenhardt, Martin 2000, Kuuluvainen 2012). Based on a critical analysis of the approaches to how dynamic capabilities are defined, the following five-stage model (fig.1) was proposed representing the capabilities-shaping process (Cyfert, Krzakiewicz 2015):

1. Sensing opportunities: This involves analysis of various trends and phenomena in the environment, creation of new ideas and identification of the need for change.

2. Learning: This involves accumulation of knowledge, intra-organisational knowledge transfers, intra-organisational knowledge allocation and retention, intellectual property management, and encouraging employees to experiment.

3. Coordination: This involves creating a vision to integrate stakeholders, building stakeholder loyalty, integrating supply chain activities, managing strategic alliances, building employee commitment, creating cohesive decision-making rules, integrating and coordinating business processes.

4. Configuration and reconfiguration: This involves creating, securing and integrating resources and skills, creating innovations, managing imitation, getting rid of (releasing) superfluous and redundant resources and skills, and deploying new technologies.

5. Organisational adaptation: This involves transforming business models, managing organisational boundaries, ensuring a dynamic strategic management process, organisational improvements, adapting and implementing best management practices, ensuring flexible organisational structure, and managing organisational identity.

As shown above, the logic of the process whereby dynamic capabilities are developed within organisations points to the significance of general innovative and imitative activities. It also underlies the research problem of this study,

9 


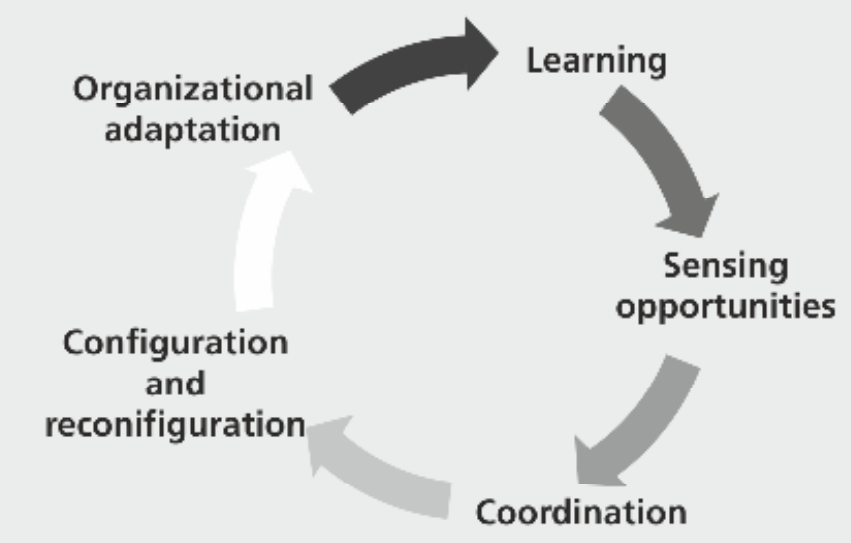

Figure 1. The process of shaping dynamic capabilities of the organisation

$$
\text { Source: own study }
$$

which is a question of how can innovative and imitative activities be integrated and synchronised within an organisation.

\section{The role of imitation in creating a competitive advantage}

In the past, imitation was often a product of coincidence rather than of thoughtout and planned activities, leading to a lot of missed business opportunities. T. Levitt's (1976) research into innovation process among some of the largest companies found that not a single one of them had any procedures that would let them respond to innovations of their competitors. The result was that imitation, even if initiated, was often ineffective.

Imitation should be a part of a general company strategy. It should be used selectively, taking into account the underlying context and capabilities of a business, and it should also be closely intertwined with innovation. Imitators usually arrive after pioneers or early followers have established their strong industry position or have saturated the market with their products. A lot of them fail, having uncritically followed the formulas of their competitors and lacking both their potential and dynamic capabilities.

Imitation is essential for the survival, evolution and wellbeing of all biological organisms. It is mostly seen in those organisms that have developed advanced cognitive capabilities. It is imitation that has largely influenced the development 
of human civilization. Without it, communities, no matter how innovative, would have suffered delays in their development.

It should be noted that most productivity gains are not so much the result of the original innovation but are derived from subsequent improvements. Imitators are capable of offering customers products that are not only better but also considerably cheaper (Drucker 2001). Where margins are thin, cost differences are of the utmost significance. Imitators can rely on them to be more competitive, from reducing their pricing through to offering high-quality products, better distribution and service, or better warranty terms. The cost savings can be earmarked for innovation, too.

Imitators are also less likely to "rest on their laurels", which is often the case with innovators and market pioneers who are often so enamoured with their success that they fail to see the potential threats. Imitators are more likely to think about others who may follow in their footsteps and are better prepared when new competitors arrive. Importantly, too, since they have a number of potential models they can use, imitators are well aware that they can follow a number of various scenarios to attain their organisational growth. They rely on this to effectively deploy further imitations and focused innovations. Unsurprisingly, then, the most profitable innovations often have a large dose of imitation in them (Bayus, Erikson, Jacobson 2008, p. 198).

There is not much difference between the importance of imitation for business and the role it plays in biology or society: it facilitates new ideas and helps organisations avoid mistakes that can sometimes have serious consequences. It will also be noted that imitation is becoming ever more feasible, more beneficial and faster because of advancements in globalisation, the codification of knowledge, and the erosion of barriers in its way.

Business scholarship needs to accept the transformation that has already happened in biology and cognitive science. They no longer see imitation as a primitive instinct but have come to regard it as a complex, intelligent and creative pursuit which requires rare and highly valuable capabilities. In order to be effective in a full-fledged imitation, today's organisations must be able to manage their imitating capabilities, from integrating models that are useful to them to an understanding of their business context. A full-fledged imitation involves identification of the causal chain and also tackles and resolves its major problem that of correspondence to the imitation target. This allows for a selection and implementation of an imitation strategy at a later stage.

In a globalised environment, no-one is safe from competitive pressures and companies which are unable to design or adapt their activities risk falling by

11

KAZIMIERZ KRZAKIEWICZ

SZYMON CYFERT 
the wayside. Rapid technological changes bring about fast product obsolescence and both inventors and first movers are usually helpless when newer products appear. Legal protection becomes weaker while codification, standardisation, new manufacturing technologies and growing employee mobility make imitation processes easier.

From globalisation to the codification of knowledge, the confluence of many variables turn the age of innovation turn into the age of imitation. The broadening of the existing channels through which knowledge is transferred, and also the addition of new ones, is another factor. New players from developing countries heavily rely on imitation to compensate for what they lack in capital and know-how. The benefits which they derive by saving on R\&D and using older technologies are very significant for their competitive position. Under these new conditions, imitation is covering an increasing array of products, services, processes and business models. It is also becoming ever more rational in terms of costs outlays and potential profits. These realities make imitation an important strategic factor which firms cannot ignore. "The days of the great mind thinking are gone, and clever imitation is called for as an effective strategy" (Bonabean 2004, pp. 45-54).

\section{From innovation and imitation to imovation}

To make sure they are successful, imitators must effectively resolve the correspondence problem. When there is no correspondence, significant problems tend to come up: imitators are unable to derive the benefits of their imitation efforts and are forced to carry their costs and risks. In fact, unsuccessful imitators do not produce true imitation. They fail to reveal the complex causal structure behind the potential results and instead create copies that miss the essential characteristics of the original product. In a lot of cases, the problem is their lack of imitation capabilities, such as a failure to promote a proper organisational culture, a failure to see promising solutions, or a failure properly to contextualise and analyse, that is a failure to characterise the models in detail and understand their distinguishing features.

In many instances, imitation lacks strategic direction. Imitators do not understand fully what they intend to imitate and what will compensate for their late market entry. Even when they are successful, imitators rarely see imitation as an element of their corporate strategy. Most often, their success is due to the errors of their competitors or some lucky coincidence where beneficial factors are a random occurrence rather than being the result of the imitator's systemic activity. 
In a world of increasing competitive pressure, this unstructured approach is not sufficient. Imitation should no longer be perceived as an embarrassing pursuit at the margins of business; rather, it should be seen as something of key importance for the organisation, both strategically and operationally. What is more, imitation and innovation are not mutually exclusive but together form an integrated system, complementing each other and producing synergy effects. As such, imitation should not be seen as an obstacle impediment to innovation but as a force which drives a well-designed innovative process.

It is now half a century ago that $T$. Levitt noted the need for developing imitation strategies, arguing that even efficiently managed firms, with managements that set a great store by innovation, would not treat imitation as "a planned and a carefully executed process" but rather as "random, secondary and relative activity... an almost blind reaction to the actions of other organisations." Not a single one of the firms which T. Levitt had studied had an imitation strategy in place (Levitt 1966, p. 65). Twenty years later, a study of 129 companies by R. C. Levin, A. K. Klevorick, R. R. Nelson and S. G. Winter (1987) found that the average number of companies which were able to imitate a process or product was $6 \%$ to $10 \%$. In the case of major processes or products, that ratio fell to $3-5 \%$. Where very complex tasks were involved (for example, copying business models) and managers were asked about their imitation strategy, the percentage would be lower still.

T. Levitt's (1966, p. 65) view that "not a single company can afford to even try and be the first in everything in its field" is truer than ever before. The environment keeps growing more complex and changeable; research and development expenditure is growing fast, too. At the same time, imitation expenditure is falling in relative terms. Even those who believe that are leaders in their industry cannot renew all elements of their business all the time.

This means that innovators should focus their efforts on a few major features of their business. When they do so, they will be in a position to develop an innovative and creative combination of both imitated and innovative elements. Managements must pay greater attention to imitation; otherwise they may get entangled in risks and expenditures involved in risky "from the scratch" pursuits while their competitors will be busy combining their innovations and imitations into a winning formula.

Innovation and imitation alone will not create long-term competitive advantage; also, there is no actual conflict between the two. These two facts lead us to conclude that it is reasonable to fuse innovation and imitation into imovation, which requires not only the ability to deter imitators but also to use 
the knowledge of how to penetrate the traditional barriers which innovators erect.

Imovators know how to create and effectively use dynamic product features associated with imitation. They know how to carry out large-scale data searches in real time, work with a number of business models, and determine the place of their product or model on the market. They can also implement their planned projects speedily and effectively, modifying them in a flexible manner depending on the changing environment. As such, imovators engage in "creative imitation" by fusing imitated elements with an innovative approach and the knowledge of their situational context.

Innovative companies often employ a strategy of causal ambiguity. This makes it difficult for outside observers to analyse and comprehend a new product, process or model. If this defence is strong, access to information alone will not be sufficient to engage in effective imitation. The imitator may see "what it looks like" but will not know "how to do it".

In practice, effective imitators, those with thorough analytical capabilities, can recreate the innovator's intricate business model structure and reduce the level of causal ambiguity. Innovative firms which are open to outside communication find it difficult to hide their internal processes without disturbing their own internal coordination or incurring significant additional costs. For example, Japanese firms often use what is called a "bottleneck" strategy whereby crucial places of key knowledge and competences can only be accessed by a small number of trusted staff. However, this strategy involves frequent transfers of ferrying expensive personnel. Moreover, if the defence is overcome, the entire system is compromised. Even an organisational culture which a lot of firms treats as an insurmountable obstacle may not be an effective barrier at all if the imitator is in a position to use its codified elements.

An in-depth analysis requires that appropriate dynamic capabilities, organisational culture and procedures are fostered within a firm that will enable it to conduct sophisticated cause-and-effect investigations. To reveal a complex imitation models, it is useful to rely on what is called decomposition, which is the cognitive separation of an act into its separate parts, the selection of critical elements, and the creation of a hierarchy of goals and means. Decomposition is carried out by an analysis of organisational behaviours, which divides activities into their component parts and helps one comprehend and discharge them or substitute their elements based on the process logic.

There is a widely-held belief in the strategic management literature that duplicating complex, system-wide and tacit knowledge is extremely difficult. 
However, history shows us that this is a regular phenomenon (Rivkin 2001; Zander, Kogut 2005). Imitators do it by arduously picking up the grains of knowledge and developing their dynamic capabilities of abstraction which business theoreticians reserves to the innovators. Imitators who are honing their process architecture knowledge can turn to partners that have necessary skills and, using their fine analytical skills, may identify substitute elements to fill in their missing skills. Also, they can simply copy visible and structured elements and thus build copies which are as effective as the original.

Finally, a lot of innovators openly communicate with their business environment in the belief that they still can keep their lead in the market game. Kodak provided its Chinese partners with information on its processes on the assumption that it would always maintain its edge one way or the other. GE argued the same when it provided turbine design documentation to its customers. While doing so, it also claimed that it was already working on nextgeneration technologies.

Imitators can maintain their competitive position by offering products with mature but proven technologies at lower prices. This is attractive to many customers. Imitators can then use their position as a basis from which to offer more modern technologies or in order to create novel combinations of existing technologies. Customers who accept whatever they are being offered may demonstrate their attachment to the transforming company because of their brand loyalty or in order to avoid provider switching costs. Obviously, the same factors may also protect innovators.

\section{Imovation challenges}

\section{Overcoming established relationships}

The existence of a complex network of internal and external relationships should be treated as a significant obstacle to penetrating or copying a value chain even if such chain is visible and well understood. For example, McDonald's uses its close relationships with suppliers and other partners as an addition to its unique operating system to create business models that cannot be replicated (Rivkin, 2010). This is consistent with a study by T. Levitt who found that effective sales and service operations were the best means of mitigating imitation.

It is very difficult to be a good imitator in all the relationships a company has with its customers. Gary Clark, CEO of Cardinal Health, claims that his company controls its relationships in "the last hundred yards", which is where medical distribution channels are directly connected with patients and medical 
personnel (Shenkar 2010, p. 156). On the other hand, a weakening of key relationships provides competitors with an opportunity to make more active moves; for this reason, imitators should monitor innovators carefully, looking for any sign of their weakening external relationships (for example, when they terminate their alliances).

The maintenance of specific relations is not always available or it may be too expensive to protect them. Signalling is one of the most common deterrents against imitation. Pioneers or innovators use it to demonstrate their dominant position so as to discourage any competition with the original. Imitators may effectively neutralise such signals. For example, publicising product quality may be neutralised by lower pricing or offering products with unique features.

Companies may signal their manufacturing overcapacity to show their potential imitators that the innovator is ready to defend "its turf" robustly and mobilise resources without which the imitator will not be capable of market entry. Building such manufacturing overcapacity is costly and involves a significant risk: if demand does not improve to meet the company's manufacturing capacity, if customers change their preferences and expectations or if here is change in technology, the strategy will of benefit to rational imitators, especially those that can offer improved products or their substitutes.

An opinion is often heard that market pioneers are protected by expenditures which customers may have to incur to switch from a technology they know and are already invested in to one for which appropriate infrastructure and competences still need to be created. However, imitators can select products for which such costs are minimal. For example, this could be software of the same type for electronic devices or equipment that is compatible with that offered by market pioneers. As a result, an imitation which is compatible with equipment that is already present on the market, and with its usage, may be more appreciated than the original. Other than that, the "no bells and whistles" versions of products will attract customers who have so far been priced out of the market and as such will incur no technology-related costs.

\section{Overcoming the problem of complementary assets}

Complementary assets, which may include specialised manufacturing, special supplies and distribution channels, may operate as barriers until the imitator gains access to the same assets or their substitutes. It is often forgotten that some imitators operate the infrastructure that is equal to or better than that of innovators. Complementary and specific assets can also be accessed by building alliances or finding providers that have them. If an innovator does not have 
robust vertical integration and is unlikely to rely on exclusive supply contracts, imitators are in a position to acquire the same resources from the same partners. Furthermore, distribution channels are increasingly controlled by large retail chains which have a large market power and can decide on what will be sold on the market.

\section{Overcoming marketing barriers}

Brand is the most common marketing barrier. It can be overcome by using private labels, acquiring some other well-known brand, partnering with other reputable companies, or offering good warranty terms. Having said that, brand remains a major barrier, especially when it is a household name, product loyalty among consumers is high, and distribution channels are controlled.

However, distribution barriers (to take that example) are only effective when a business scale or production volume advantage is significant and sales channels are either limited or concentrated. Otherwise, the imitator will have no problem challenging the innovator.

According to marketing theoreticians, consumers will prefer the first product on the market, if its features are known and become a standard for comparison with its subsequent versions. This does not prevent the imitator from offering something better, cheaper, or deemed to provide a greater value to the buyer. Some consumers may prefer products which have been tried and tested over a longer period of time, but others will have an interest in what is new, especially if the novelty is superior to the original in some respects. A lot of consumers are risk averse; they do not want to try a new product or do not feel that an existing product is becoming obsolete. By continuing to buy from the pioneer, they may reduce the expenditure involved in searching for alternatives and avoid uncertainty about how to use the new product. That said, substitute search costs are low in the Internet age, and there are many intermediaries who do the data collection work. Given that end product manufacturers are increasingly joining their production efforts with other manufacturers (e.g. as part of cooperative arrangements), imitators can nearly as easily try and differentiate as innovators.

In addition, innovators are advised to reposition their products, processes or business models, moving them from saturated segments into the ones in which imitators are few and far between or where they are unlikely to appear. This type of barrier is essentially temporary because imitators will move to promising markets as they develop their dynamic capabilities.

A lot of companies believe that top-quality process execution may safeguard them against imitators. This is not always the case. Competitors often find

17

KAZIMIERZ KRZAKIEWICZ

SZYMON CYFERT 
appropriate substitutes, source production to effective and efficient firms, and improve supply chains. In practical terms, imitators with suitable dynamic capabilities can have the edge by creating a robust product or business model whilst innovators will be trying to cope with organisational problems.

All of this shows that imitators must learn how to overcome imitation barriers and, at the same time, use those barriers to prevent other imitators. Imitators must be capable of resolving the contradictions between the free flow of information which is necessary for innovation processes and the development of intellectual capital needed to deter their competitors.

Some innovative companies (e.g. $P \& G$ ) use a varied approach. In addition to legal measures (patents, trademark registration, etc.), they use what is called "assembler defence" whereby each of their partners or suppliers only sees part of the whole, with the management of the company concerned alone seeing the "big picture". Such companies use proprietary technologies and production systems, the information of which is compartmentalised. Only selected employees have the full knowledge of the technology involved and how in-house processes are designed. Importantly, too, these measures are accompanied by innovative activities which actively look for learning and commercialisation opportunities.

\section{Principles of imovation}

The first step towards imovation involves actions that are common to the two forms of activity. Imitation and innovation are not that far apart as it may seem. A lot of the skills and capabilities required of effective innovators are also needed for effective imitation. Both kinds of activity require fast evaluation of any new information that comes from the outside. Both also make it necessary to jettison an overly simplistic view of the situation in order to replicate a complex and incomprehensible reality. Both innovators and imitators must analyse the intricate structure of that reality, and they must also carry out in-depth causal analyses within their relevant business contexts. They rely to in an equal measure on multiple models and change, select or order any potential opportunities, variants of actions or their combinations. They also improvise in response to a rapidly changing environment.

In practice, imitators' advantage over innovators is in their wider search net and their ability to identify and analyse activities of firms in other sectors. Imitators observe and assess huge amounts of outside information and for this reason must identify and select data, and then assess such data in their specific context. This is similar to what innovators do to turn their inventions into innovations. 
Innovators are often so focused on their novelties that they cannot see their practicalities and the context in which they are to be used. Imitators have to catch up with others quickly and react operationally to any problems and opportunities as they arise. For this reason, a lot of them (especially fast seconds/ quick imitators) acquire rapid new project implementation skills. These skills are also useful to innovators when new solutions come up abruptly, in unexpected places, and require to be quickly transformed into various applications.

At the same time imitators, as just innovators, bring business benefits by showing their creativity, using their "creative imitation" to build more usable products at a lower cost.

\section{Conclusion}

The assumption that modern companies are forced to compete in the "age of imitation" is a premise for more general conclusions. These conclusions can also be used as management guidelines:

- firms which ignore the benefits of imitation do so at a risk to their development,

- the pace of imitation is correlated with, or sometimes even faster than, the pace of innovation,

- some imitators are successful, whereas others fail because they lack dynamic capabilities or implement their strategic planning processes improperly,

- imitation should not be seen as a substitute for innovation. rather, it should be seen as a complementary activity which can stimulate innovation if done properly,

- once fused, imitation and innovation create imovation in order to create competitive advantages.

A set of capabilities can also be defined that need to be honed to ensure that imitation is a highly effective endeavour:

- prepare: Culture and behaviours need to be developed that not only accept imitation but also promote and support it just as much as innovation,

- correlate: This is the ability to determine and focus on behavioural models which are potentially useful for imitation,

- search, identify and select: This is the ability to look for, identify and select products, processes, services, procedures, ideas and models that need to be replicated,

- contextualise: This is the ability to identify appropriate environmental factors and analyse both the original and the copy in their underlying context,

- deep dive: This is the ability to conduct in-depth investigations that go beyond 
a simple analysis of correlations, and involve complex cause-and-effect relationships,

- execute: This is the ability to master a new idea rapidly and effectively execute targets of imitation.

Innovation is a crucial factor in the survival, growth and development of a firm. It is a source of profits derived from a monopoly position which companies may tap into until imitators inevitably show up. It does not take long for the most enterprising and efficient imitators to surpass the creator of the original, from then on a minor player on the huge market formed through imitation. In practice, despite negative stereotypes, many imitators are so successful in their business that the innovator is left well behind.

\section{Summary}

\section{Imovation in shaping dynamic capabilities of organisations}

The underlying assumption of the article is that imitation is as important as innovation when creating a long-term competitive advantage, and that a systematic, strategic approach to imitation is necessary to ensure efficient and effective innovation. Viewed in this light, imitation is a rare and complex dynamic capability which organisations should properly develop and skillfully use. Imitators provide customers with products that are both better and cheaper. This article contributes to a discussion of innovative processes and their role in shaping dynamic capabilities of organisations. It attempts to portray the essence and nature of imitation and identifies benefits which copying what other organisations do can bring in terms of dynamic capabilities.

Key words: dynamic capabilities, imovation, innovation, imitation.

\section{Streszczenie}

Imowacje w procesie kształtowania dynamicznych zdolności organizacji

U podstaw opracowania leży założenie, iż imitacja jest tak samo istotna dla budowy długofalowej przewagi konkurencyjnej jak innowacja, i że systematyczne strategiczne podejście do imitacji jest konieczne dla zapewnienia skutecznej i efektywnej działalności innowacyjnej. W takim ujęciu imitacja stanowi rzadką i złożoną zdolność dynamiczną, którą organizacje powinny we właściwy 
sposób rozwijać i umiejętnie wykorzystywać. Imitatorzy dostarczają odbiorcom nie tylko udoskonalony, lecz także tańszy produkt. W opracowaniu, włączając się w dyskusję nad procesami innowacji w kształtowaniu dynamicznych zdolności organizacji, podjęto próbę przedstawienia natury $\mathrm{i}$ istoty imitacji, wskazując na korzyści wynikające z umiejętnego kopiowania działań innych podmiotów dla realizacji procesu kształtowania dynamicznych zdolności.

\section{Słowa}

kluczowe: Dynamiczne zdolności, imowacje, innowacje, imitacje.

\section{References}

1. Bayus B. L., Erikson G., Jacobson R., 2008, The financial rewards of new product introductions in the personal computer industry, Management Science, Nr 2/49, p. 198.

2. Bonabean E., 2004, The perils of the imitation age, Harvard Business Review, June 2004, pp. 45-54.

3. Cyfert Sz., Krzakiewicz K., 2015, Procesy poszukiwania okazji i uczenia się $\mathrm{w}$ kształtowaniu dynamicznych zdolności polskich przedsiębiorstw [w:] Rokita J. [red.], Nauki o Zarządzaniu wobec nieprzewidywalności i złożoności zmian, GWSH.

4. Drucker P.F., 2001, The essential Drucker, Harper Business, New York.

5. Eisenhardt K. M., Martin J. A. (2010), Dynamic capabilities: What are they?, Strategic Management Journal, 21 (10-11), pp.1105-1121.

6. Kuuluvainen A., (2012), International Growth of a Finnish High-Tech SME: A Dynamic Capabilities Approach, Research In Economics and Business: Central and Eastern Europe, Vol 4., No 2, 26-40

7. Levin R. C., Klevorick A. K., Nelson R. R., and Winter S. G., (1987) Appropriating the returns from industrial research and development, Brookings Papers on Economic Activity No. 3, pp. 783-820.

8. Levitt T., 1966, Innovation and imitation, Harvard Business Review, September - October, pp. 69-70.

9. Levitt T., 1976, The Industrialization of Service, Harvard Business Review, September - October, pp. 63-74.

10. Rivkin J. M., 2010, Imitation of complex strategies, Management Science $\mathrm{Nr}$ 46, pp. $824-844$.

11. Rivkin J.W., 2001, Reproducing knowledge, Organization Science Nr 12, pp. 274-293.

12. Shenkar O., Copycats. 2010, How Smart Companies Use Imitation to Gain a Strategic Edge, Harvard Business Press, Boston, p. 25. 
13. Teece D. J. (2008), Dynamic capabilities.[In]: Lazonick W. (ed.), The international Encyclopedia of Business and Management. Thomas Learning Publishers, London, pp. 1497-1512.

14. Zander U., Kogut B., 2005, Knowledge and the speed of transfer and imitation of organizational capabilities, Organization Science No. 6. 